\title{
Incidences of Infectious Diseases in Freshwater Aquaculture Farms of Eastern India: A Passive Surveillance based Study from 2014-2018
}

\author{
Sahoo PK ${ }^{1 *}$, Paul A ${ }^{1}$, Sahoo MK ${ }^{1}$, Pattanayak S ${ }^{1}$, Rajesh Kumar P1, Das BK ${ }^{2}$ \\ ${ }^{1}$ Fish Health Management Division, ICAR-Central Institute of Freshwater Aquaculture, India; ${ }^{2}$ ICAR Central Inland Fisheries Research \\ Institute, India;
}

\begin{abstract}
During the period 2014-18, a total of 219 cases of fish mortalities were being investigated under a passive surveillance programme. Among different disease incidences parasitic diseases were found to the major contributor accounting for $74.88 \%$ cases followed by bacterial diseases of $12.79 \%$, mixed bacterial and parasitic diseases of $10.50 \%$ and viral diseases of $1.83 \%$. Among different parasitic cases mixed parasitic infections (37.80\%) were found to be premier cause of disease followed by Argulosis (19.51\%), Dactylogyrosis (18.90\%), Myxosporean infections (12.80\%), Trichodinosis and Ichthyophthiriasis (3.04\%) and other parasitic infections (4.88\%). Among bacterial infections, aeromonads group account for $66.66 \%$ diseases besides few emerging pathogens of public health significance. Catla was found to be the most susceptible species and winter season being the most favorable season for occurrence of infectious diseases. Fishes weighing 100-500 g were most vulnerable to disease occurrence. This study generated a comprehensive disease incidence scenario in freshwater aquaculture in eastern India.
\end{abstract}

Keywords: Bacterial infections; Disease incidences; Parasitic infections; Passive surveillance; Viral infections

\section{INTRODUCTION}

The total fish production of India during 2015-16 (provisional) was 10.79 million metric tonne (MMT) (DAHDF Annual Report 20162017) in which aquaculture contributed to more than $60 \%$ of total production. The spreading out, diversification and intensification of aquaculture practices bring several health related problems during culture, and disease may become a significant constrain. Fishes are being commonly encountered with different group of pathogens including virus, bacteria, fungus, parasites etc. [1]. Mohan and Bhatta [2] described the extent of social and economic impact of two important fish diseases namely epizootic ulcerative syndrome (EUS) and white-spot disease on rural aquaculture. Gopal et al. [3] recorded parasitic disease incidences as most prevalent among all other diseases in India. Recently because of the proper monitoring and intense surveillance several fish viral diseases have been reported from the country which was earlier neither been detected nor been reported, e.g. cyprinid herpes virus 2 [4], carp edema virus [5], tilapia lake virus [6], ranavirus [7], etc. As aquaculture expands and intensifies the economic loss due to diseases is likely to increase in many fold [2]. There are many missing links in the disease prevalence scenario in India which only can be fulfilled with structured and continuous monitoring and surveillance.

Although there are some studies available related to disease occurrence and seasonality in India [8] but concrete evidence based on systematic surveillance regarding different disease incidences throughout the year is not available in freshwater aquaculture sector. Passive surveillance is very important tool to be used for finding out the disease prevalence including in fishes. Most of the times disease incidence reports goes in vein as the farmers don't report it. Structured study is very much essential to bring out the disease incidences over the time to draw a year based prediction for fish diseases. Epidemiological characteristics of most of the fish diseases are very much unclear. In this study, clinical cases collected/ received from eastern parts of Indian states, viz., Odisha, Andhra Pradesh, Chhattisgarh and West Bengal have been diagnosed using reliable laboratory based tools (from Level I to Level III) to identify different disease conditions for the entire study period (2014-2018) and the disease incidences are being grouped as per the pathogen types, seasonality, size and species involved to draw a preliminary current scenario.

Correspondence to: Pramoda Kumar Sahoo, Fish Health Management Division, ICAR-Central Institute of Freshwater Aquaculture, India, Tel: +91 6742465421; Fax: +91 6742465407; E-mail: pksahoo1@hotmail.com

Received: August 14, 2019, Accepted: January 24, 2020, Published: January 30, 2020

Citation: Sahoo PK, Paul A, Sahoo MK, Pattanayak S, Rajesh Kumar P, Das BK, et al. (2020) Incidences of Infectious Diseases in Freshwater Aquaculture Farms of Eastern India: A Passive Surveillance based Study from 2014-2018. 11: 579. doi: 10.35248/2155-9546.20.10.579

Copyright: (C) 2020 Sahoo PK, et al. This is an open access article distributed under the term of the Creative Commons Attribution License, which permits unrestricted use, distribution, and reproduction in any medium, provided the original work is properly cited. 


\section{MATERIAL AND METHODS}

\section{Diseased fish samples}

The freshwater fish samples either received in our laboratory (National Referral Laboratory for Freshwater Fish Diseases, ICARCIFA, Bhubaneswar, Orissa) or collected during surveillance programme were included in this study.

The study was carried out between March, 2014 to February, 2018 to find out different disease incidences in freshwater fish farms of eastern India mostly. The samples were mostly collected or received in our laboratory from two important aquaculture states of India (Odisha and Andhra Pradesh) besides few cases from neighbouring states (Jharkhand, Chhattisgarh and West Bengal). Prior to sample collection, a large numbers of extensive awareness programs on fish diseases were being organized during the period to receive disease specimens with desired transporting conditions from different parts. Besides, the laboratory also collected samples from farm sites upon being reported by the farmers or state officials or being noticed during frequent visit to few farms. Disease diagnosis has been carried out using all the three levels of diagnosis as per requirement. The samples upon collection were being stored in $10 \%$ neutral buffer formalin (NBF) for histological, $100 \%$ ethanol for DNA based study, and in RNAlater for RNA based study. Samples of parasites were either preserved in $4 \%$ NBFor directly examined from squash preparation of skin, gills and kidney tissues under the microscope. For bacteriology, the samples were aseptically collected in tryptone soy broth for further study. Confirmatory diagnosis using Level-III diagnostics was being implemented for most of the cases. Species level diagnosis of different bacteria, virus and parasites was being carried out using polymerase chain reaction (PCR) and molecular sequencing following earlier published methods for each of the pathogens. The details of the tools and techniques followed for diagnosis of each case and pathogen are beyond the scope of this paper and dealt or published elsewhere based on the importance of the pathogens. Briefly, the bacterial pathogens listed here were being diagnosed based on species-specific PCRs along with 16s rDNA sequencing. Parasites were mostly identified based upon microscopy, although PCR was used for further species level confirmation. Viral disease diagnosis was based on level III diagnosis using molecular tools. The mortality cases due to bad water qualities and poisoning were excluded from this study to draw conclusion of only infectious cases.

\section{Data analysis}

The data obtained were analyzed using descriptive and tabular statistical methods. The analytical methods included conversion of raw data to meaningful results using distribution, ratio and percentage.

\section{RESULTS AND DISCUSSION}

The study primarily explains about prevalence of different fish diseases, host/size preference, and seasonality of infections that occurred during 2014-2018 mainly at different parts of eastern India in the major freshwater aquaculture farms. The results obtained seem to be a reflection of generalized picture for the whole country although it was beyond the scope of the present study in our laboratory. The collected/received samples analyzed during the study period gave a clear indication that parasites play critical role in aquaculture being the major share to the list of pathogens.

\section{Incidences of diseases}

Among different infectious diseases, parasitic diseases were found to be the major cause of disease incidences in the freshwater aquaculture sector. During the period, a total 219 cases were being registered among which incidences of parasitic diseases accounted for $74.88 \%$ followed by bacterial diseases (12.80\%), mixed bacterial and parasitic diseases $(10.50 \%)$ and viral diseases $(1.83 \%)$ (Figure 1). Among the viral diseases, $75 \%$ of the diseases reported were from ornamental fishes and $25 \%$ from food fishes. In total, three viruses viz., cyprinid herpesvirus 2 causing goldfish haematopoietic necrosis, carp edema virus and betanodavirus (from wild seabass seeds) were being diagnosed. Fagbenro et al. [9] described parasitic diseases having most significant impact on aquaculture production and health management. In India, Gopal et al. [3] also recorded different parasitic pathogens being the major disease causing agents ( $70 \%$ of cases) in the sector followed by bacterial $(27.5 \%)$ and fungal (2.5\%) ones. However, the present study did not reveal any incidence of fungal infection related mortality in fish farms. Further, the later study described the incidences based on level I or level II diagnosis.

\section{Incidences of parasitic diseases}

The parasitic disease incidences were the major disease causing agents found in this study. Among 164 cases of parasitic infections, mixed parasitic infections $(37.80 \%$ ) were found to be premier disease causing agents leading to mortality followed by Argulus sp. (19.51\%), Dactylogyrus sp. (18.90\%), myxosporean infections (12.80\%), trichodinosis and (3.04\%) infections and other parasites (4.88\%) that include Lernaea, Epistylis, Glossiphonia complanata, Metanophrys sinensis, Zoothamnium spp. (Figure 2). Within the mixed parasitic infections, association of exclusively different gill parasites were found to be $57.65 \%$ whereas association of both gill and skin parasites were found to be $42.35 \%$. Among individual pathogens, Argulus spp. was found to be the most devastating pathogen followed by Dactylogyrus and other parasitic pathogens. Argulosis alone has been described as the major cause of crop loss in Andhra Pradesh throughout the culture period [8].

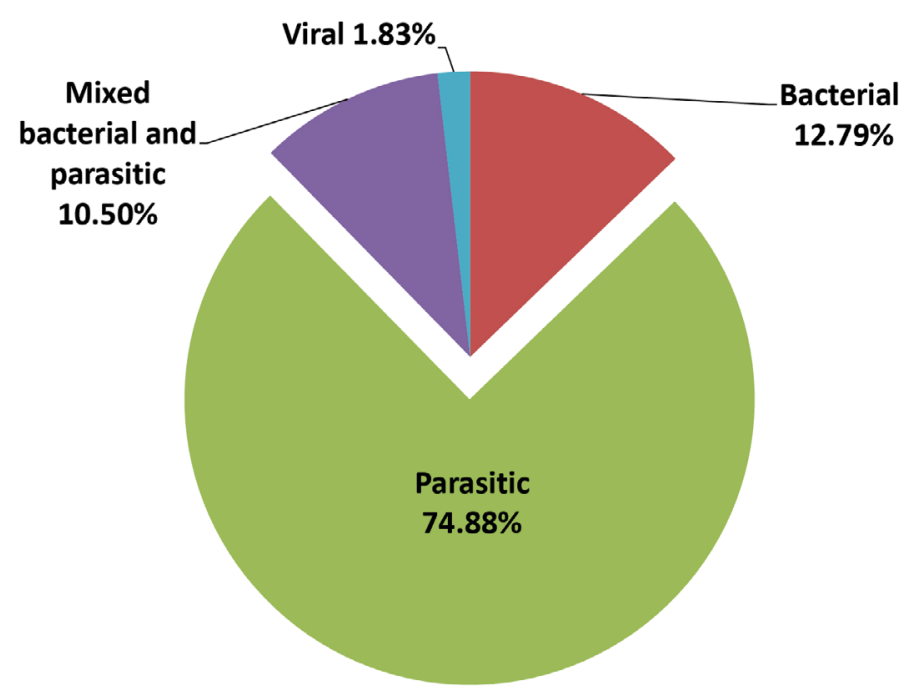

Figure 1: Incidences of different diseases during the period (2014-2018). 


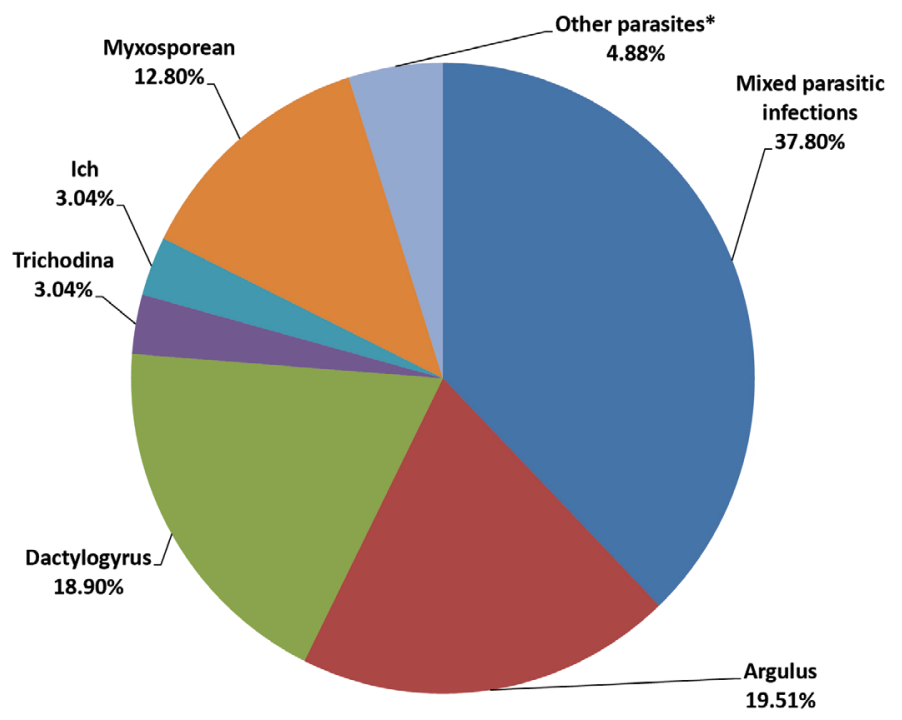

*Other parasites: Lernaea, Epistylis, Glossiphonia, Metanophrys, Zoothamnium spp.

Figure 2: Incidences of different parasitic diseases during the period (20142018).

\section{Incidences of bacterial diseases}

Bacterial disease is one of the major problems in fish production. During the study incidences of lone bacterial infections, and mixed bacterial-parasitic infections were mostly noticed. Aeromonads group among all the bacterial pathogens was found to be major pathogens causing bacterial fish diseases (66.66\%). Within the aeromonads group, Aeromonas hydrophila (52.94\%) was found to be involved in maximum number of disease cases followed by A. sobria (26.47\%), A. veronii (14.70\%), A. jandei (2.94\%) and A. caviae (2.94\%). Karunasagar et al. [10] reported motile aeromonad infections causing mortalities in IMC farms in India and marked as one of the major bacterial pathogens of fishes. Aeromoniasis also described as one of the major threats for IMC farming in India [11]. Other than aeromonads, many emerging bacterial pathogens were also recorded to be associated with causing fish mortality i.e., Klebsiella pneumoniae, Edwardsiella tarda, Proteus mirabilis, Plesiomonas shigelloides, Acinetobacter baumannii, Morganella morganii and Serratia marcescens. The above bacterial pathogens were found to be virulent as observed in our laboratory challenge study (Data not shown here) (Figure 3). Vibrio harveyi and V. parahaemolyticus were also found causing mortality in giant freshwater prawn Macrobrachium rossenbergii hatchery. Further one case of ornamental fish red eye tetra (Moenkhausia sanctaefilomenae) infected with acid fast bacteria causing tumor like growth at the head portion of the fish was also found. Histopathogical observation clearly revealed granuloma with presence of acid fast bacteria in the centre of the granulomatous tissue (Figure 4) with acid fast staining. All the bacteria were confirmed by level III diagnosis based on $16 \mathrm{~s}$ rDNA sequencing and species-specific PCR followed by challenge tests. Further, most of the bacterial pathogens were also found to be multi-drug resistant (data not shown here). Thus, it is alarming for aquaculture farms and farmers and consumers, and it needs targeted surveillance for few human pathogens in the sector to bring a clear picture and sensitize the farmers about anti-microbial resistance and alternate drug use.

\section{Species-wise disease incidence}

Most of the cases were obtained from Indian major carp farming.
Among Indian major carps, Catla was found to be most susceptible fish species followed by rohu and mrigal. Vineetha [8] also noticed infections in C. Catla and L. rohita, as being mostly cultured fish species. Among the three Indian major carps, Catla was most prone to infectious diseases followed by Mrigal and Rohu [12] as also noticed here. As evident here, Catla was found to be more susceptible to disease conditions probably being a surface feeder and more commonly vulnerable to water temperature fluctuations leading to weaken immunity. However, experimental studies are needed to draw such conclusive information on species and size susceptibilities to different disease conditions. Further, disease incidences in Channa striata farming, ornamental fish and wild seabass seeds collected for stocking in freshwater ponds were also recorded. Details of species-wise disease incidences are described in Table 1.

\section{Seasonality in occurrence of diseases}

Several authors have described influence of seasonality allied to feeding habit of hosts, immunological amendments, intermediate host's availability, hormonal balance, and alteration in temperature and other water quality parameters being the most common factors leading to seasonal fluctuation in prevalence of parasitic infections [13-15]. The complete year was divided into 3 major seasons i.e., summer (March-June), monsoon (July-October) and winter (November-February) [16-18] Disease incidences were being noticed throughout the year, however, winter season was found to be the most favorable season for disease occurrence in aquaculture farms in the studied region during the study period. Total 89 cases out of 219 cases were being recorded during winter. As described earlier, the reduced water temperature along with weaken immune

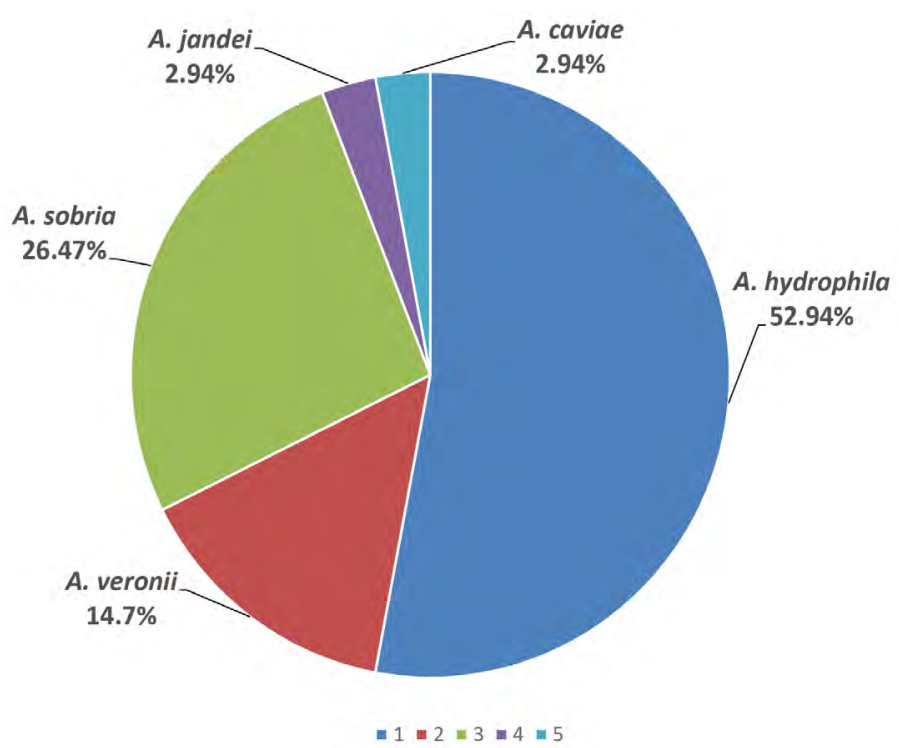

Figure 3: Different species of aeromonads bacterial group causing fish mortality.

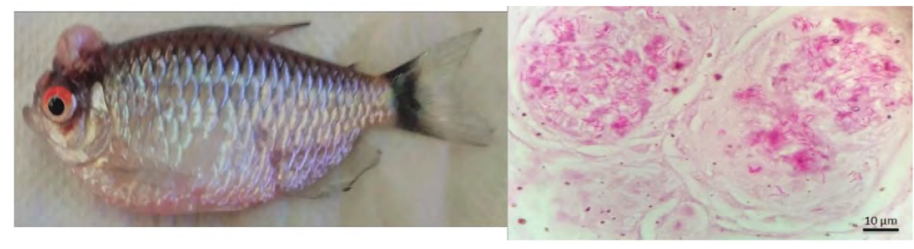

Figure 4: Acid fast bacterial infection in red eye tetra, Moenkhausia sanctaefilomenae. 


\begin{tabular}{|c|c|c|c|c|c|}
\hline Fish & $\begin{array}{c}\text { No. of bacterial } \\
\text { disease incidences }\end{array}$ & $\begin{array}{l}\text { No. of parasitic } \\
\text { disease incidences }\end{array}$ & $\begin{array}{l}\text { No. of mixed bacterial } \\
\text { and parasitic disease } \\
\text { incidences }\end{array}$ & $\begin{array}{l}\text { No. of viral disease } \\
\text { incidences }\end{array}$ & Total \\
\hline Catla (Catla catla) & Nil & 48 & 4 & Nil & 49 \\
\hline Rohu (Labeo rohita) & Nil & 39 & 7 & Nil & 45 \\
\hline Mrigal (Cirrhinus mrigala) & Nil & 1 & Nil & Nil & 1 \\
\hline Rohu and Catla & 7 & 30 & 5 & Nil & 40 \\
\hline Catla and mrigal & Nil & 4 & Nil & Nil & 4 \\
\hline Rohu and mrigal & Nil & 2 & 2 & Nil & 4 \\
\hline Indian major carps & 4 & 20 & 2 & Nil & 24 \\
\hline Ornamental fishes & 8 & 5 & 3 & 3 & 17 \\
\hline Exotic carps & Nil & 3 & Nil & Nil & 3 \\
\hline $\begin{array}{c}\text { Pangas (Pangasianodon } \\
\text { hypophthalmus) }\end{array}$ & Nil & 1 & Nil & Nil & 1 \\
\hline M. rosenbergii & 1 & 3 & 1 & Nil & 5 \\
\hline Labeo bata & Nil & Nil & 1 & Nil & 1 \\
\hline $\begin{array}{c}\text { Channa striata, C. marulius and } \\
\text { Anabas testudineus }\end{array}$ & 1 & 6 & 3 & Nil & 10 \\
\hline Amblypharyngodon mola & 1 & Nil & Nil & Nil & 1 \\
\hline Tilapia (Oreochromis niloticus) & 1 & Nil & Nil & Nil & 1 \\
\hline $\begin{array}{l}\text { Freshwater mussel (Lamellidens } \\
\text { marginalis) }\end{array}$ & Nil & 1 & Nil & Nil & 1 \\
\hline Clarias batrachus & Nil & 1 & Nil & Nil & 1 \\
\hline Lates calcarifer & Nil & Nil & Nil & 1 & 1 \\
\hline
\end{tabular}

Table 1: Fish species-wise incidences (number) of different diseases.

\begin{tabular}{ccccc}
\hline Seasons / Year & Summer & Monsoon & Winter & 19 \\
\hline $2014-15$ & 15 & 12 & 11 \\
\hline $2015-16$ & 7 & 8 & 39 \\
\hline $2016-17$ & 2 & 27 & 20 \\
\hline $2017-18$ & 42 & 64 & 89 \\
\hline Total & 66 & 17 & \\
\hline
\end{tabular}

Table 2: Seasonal variation in incidences (number) of different diseases.

system might be playing significant role to increase the susceptibility of fish to different infections. In summer and monsoon, 66 and 64 numbers of cases, respectively were being registered in this study (Table 2). Dash et al. [18] also mentioned winter as the advantageous season for disease occurrence as in winter fishes become immunologically weak due to low temperature stress and other deteriorated water quality related problems. Hasan et al. [19] also reported winter season as the most vulnerable season for fish disease occurrence based on the farmer's interaction-based study in Bangladesh.

\section{Fish size-wise disease prevalence}

Diseased fishes collected/received (only carps) were primarily divided into three categories i.e., $<100 \mathrm{~g}, 100-500 \mathrm{~g}$, and $>500 \mathrm{~g}$. All the different sizes of the fishes were found to get infected with different diseases throughout the study period. Fishes weighing $100-500 \mathrm{~g}$ were found to be most vulnerable to disease outbreaks followed by $>500 \mathrm{~g}$ and $<100 \mathrm{~g}$ groups. The incidences of diseases in fishes weighing $100-500 \mathrm{~g}$ were found to be $46.75 \%$ as compared to fish weighing $>500 \mathrm{~g}$ showing incidences of $32.46 \%$ and $20.78 \%$ in $<100 \mathrm{~g}$ size group. Perhaps the stocking related stress during initial stocking period at that size followed by winter stress during that attained size period might be governing the vulnerability to infections. Although not much information is available in this regard, a study conducted by Parida et al. [20] with regard to argulosis and size of fish revealed pre-adult individuals of L. rohita being more susceptible to A. siamensis as compared to other age groups.

\section{CONCLUSION}

Among bacterial infections, aeromonads group account for $66.66 \%$ diseases besides few emerging pathogens of public health significance. Catla was found to be the most susceptible species and winter season being the most favorable season for occurrence of infectious diseases. Fishes weighing 100-500 g were most vulnerable to disease occurrence. This study generated a comprehensive disease incidence scenario in freshwater aquaculture in eastern India. The present study provided apprehensive evidence about different disease incidences throughout the culture period during 2014-2018 and also opened up scope to strengthen both passive and active targeted surveillance in few of the areas of concern.

\section{ACKNOWLEDGEMENTS}

The authors are thankful to the Director, ICAR-Central Institute of Freshwater Aquaculture, Kausalyaganga, Bhubaneswar, India for 
providing necessary facilities during this study. Funding support under the NFDB-NBFGR project on National Surveillance Programme for Aquatic Animal Diseases is duly acknowledged.

\section{REFERENCES}

1. Axelrod HR, Untergasser D. Handbook of fish diseases. Neptune, NJ: TFH Publications. 1989.

2. Mohan CV, Bhatta R. Social and economic impacts of aquatic animal health problems on aquaculture in India: 63-75. In: Arthur JR, Phillips MJ, Subasinghe RP, Reantaso MB, MacRae IH. (Eds.) Primary Aquatic Animal Health Care in Rural, Small-scale, Aquaculture Development. FAO Fisheries Technical Paper. 2002; 406.

3. Gopal Rao K, Mohan CV, Seenappa D. The use of chemotherapeutic agents in fish culture in India. In: Diseases in Asian Aquaculture Shariff MRP, Subasinghe and Arthur JR. (Eds.) 1992; 505-513.

4. Sahoo PK, Swaminathan TR, Abraham TJ, Kumar R, Pattanayak S, Mohapatra A, et al. Detection of goldfish haematopoietic necrosis herpes virus (Cyprinid herpesvirus-2) with multi-drug resistant Aeromonas hydrophila infection in goldfish: First evidence of any viral disease outbreak in ornamental freshwater aquaculture farms in India. Acta Trop. 2016; 161: 8-17.

5. Swaminathan TR, Kumar R, Dharmaratnam A, Basheer VS, Sood N, Pradhan PK, et al. Emergence of carp edema virus in cultured ornamental koi carp, Cyprinus carpio koi, in India. J Gen Virol. 2016; 97: 3392-3399.

6. Behera BK, Pradhan PK, Swaminathan TR, Sood N, Paria P, Das A, et al. Emergence of Tilapia Lake Virus associated with mortalities of farmed Nile Tilapia Oreochromis niloticus (Linnaeus 1758) in India. Aquaculture. 2018; 484: 168-174.

7. George MR, John KR, Mansoor MM, Saravanakumar R, Sundar P, Pradeep V. Isolation and characterization of a ranavirus from koi, Cyprinus carpio L., experiencing mass mortalities in India. J Fish Dis. 2015; 38: 389-403.

8. Vineetha P, Abraham TJ. Assessment of fish health problems in freshwater aquaculture systems of Andhra Pradesh, India. Indian J Fish. 2009; 56: 335-337.

9. Fagbenro OA, Madedire CO, Owoseeni EA, Ayotunde EO. Studies on the biology and aquaculture potential of feral catfish Heterobranchus bidosalis. Trop Zool. 1993; 16: 67-79.

10. Karunasagar I, Ali PK, Jeyasekaran G, Karunasagar I. Ulcerative form of Aeromonas hydrophila infection in Catla Catla. Curr Sci. 1986; 55: 1194-1195.

11. Sahoo PK, Mahapatra KD, Saha JN, Barat A, Sahoo M, Mohanty BR, et al. Family association between immune parameters and resistance to Aeromonas hydrophila infection in the Indian major carp, Labeo rohita. Fish Shellfish Immun. 2008; 25: 163-169.

12. Khatri S, Sahu J, Prasad MM. Prevalence of fish diseases in Sambalpur, Orissa, India. Asian Fisheries Science. 2009; 22: 569-581.

13. Hynes HBN. The food of freshwater sticklebacks (Gasterostaus aculeatus and Pygosteus pungitius), with a review of methods used in studies of the food fishes. J Animal Ecol. 1950; 19: 36-58

14. Chappell LH. The parasites of the three spined stickleback Gasterosteus aculeatus L. from a Yorkshire pond. II. Variation of the parasite fauna with sex and size of fish. J Fish Biol. 1969; 1: 339-347.

15. Pennycuick L. Seasonal variations in the parasite infections in a population of three spined sticklebacks, Gasterosteus aculeatus L. Parasitology. 1971; 63: 373-388.

16. Kumari J, Sahoo PK, Swain T, Sahoo SK, Sahu AK, Mohanty BR. Seasonal variation in the innate immune parameters of the Asian catfish Clarias batrachus. Aquaculture. 2006; 252: 121-127.

17. Swain P, Dash S, Sahoo PK, Routray P, Sahoo SK, Gupta SD, et al. Non-specific immune parameters of brood Indian major carp Labeo rohita and their seasonal variations. Fish Shellfish Immun. 2007; 22: 38-43.

18. Dash P, Patel S, Dixit A, Garg LC, Sahoo PK. Four pro-inflammatory cytokines of rohu (Labeo rohita) during early developmental stages, their tissue distribution and expression by leucocytes upon in-vitro stimulation. Fish shellfish immun. 2015; 47: 913-922.

19. Hasan MM, Faruk MAR, Anka IZ, Azad MA. Investigation on fish health and diseases in rural pond aquaculture in three districts of Bangladesh. J Bangladesh Agric Univ. 2014; 11: 377-384.

20. Parida S, Mohapatra A, Mohanty J, Sahoo PK. Labeo rohita and Argulus siamensis infection: Host size, local inflammatory reaction and immunity modulate ectoparasite load on fish. Aquac Res. 2017; 49: 757-766. 